\title{
HUBUNGAN ANTARA POLA BELAJAR DENGAN PRESTASI BELAJAR IPA PADA SISWA SMP YPK BETHEL AIMAS
}

\section{SELVINA GINUNY}

Prodi Biologi STKIP Muhammadiyah Sorong

\begin{abstract}
ABSTRAK
Penelitian ini bertujuan untuk mengetahui Pola Belajar Dengan Prestasi prestasi Belajar IPA pada Siswa SMP YPK Bethel Aimas. Dan kemampuan pola Berpikir siswa mata pelajar IPA pada tahun pelajaran 2015/2016. Populasi dari SMP YPK Bethel Aimas. Sampel dalam penelitan ini sebanyak 22 siswa dari populasi sebanyak 22 siswa yang di kelasa VIIIA. Teknik sampling yang digunakang adalah manual. Hasil peniliutian menunjukan bahwa pola pembelajaran langsung atau koperatif nilai prestasi tertinggi baik $22 \%$ dan cukup 22\% adalah pola pembelajaran kapasitas vital paru-paru, terdapat pengaruh pola pembelaran terhadap kreativitas siswa sebesar 18\% dan terdapat pengaruh pola prestasi pembelajaran sebesar 90 Sumbangan efektif terhadap kreativitas siswa pada pola pembelajaran cukup sebesar 22 dan kemampuan pola berpikir sebesar $4,54 \%$. Sehingan terdapat pengaruh yang signifikan antara pola pembelajaran dan prestasi terdapat pengaruh kemampuan pola berpikir terdapat pengaruh antara pola pembelajaran dan prestasi terdapat IPA.
\end{abstract}

Kata Kunci: Pola Belajar, dan Prestasi Belajar.

This study aimas to determine the pattern of chievement Achievement Learning With Science Claass at Bethel Junior High School Students YPK Aimas. Thinking patterns and she abilty of Students" eyes IPA Students in the academic year 2015/2016. The population of SMP YPK Bethel Aimas. The Samle in thin research were 22 Students out of a population of 22 Students the hump VIII A. Digunakan sampling technique. Results peniliutian shwed that the pattern of direct learning or cooperative volue of the highest achievements both $22 \%$ and enough $22 \%$ are learning patterns the vital capacity of the lungs, there is a pattern influence pebelaran for the creativity of Students by $18 \%$ and there are significant achievement patterns of learning by $90 \%$ effective contribution to the creativity Students in the learning pattern enough at 22 and patterns of thinking ability of 4.54\%. Sehingan a significant difference between the patters of learning and achievement are thinking patterns influence the ability there is influence between learning and achievement patterns contained IPA.

Keywords: Pattern Learning, Achievement Learning.

\section{PENDAHULUAN}

Bidang pendidikan merupakan prioritas yang harus di utamakan bagi suatu bangsa. Dengan pendidikan akan diperoleh sumber daya manusia yang berkualitas, yang akan memajukan bangsanya. sumber daya manusia yang berkualitas ini merupakan aset besar bagi suatu bangsa, karena akan menentukan keberhasilan pembangunan.

Pendidikan memegan peranan penting dalam usahan untuk mencapai manusia seutuhnya. Dalam undang-undang RI No. 20 tahun 2013 pasal 3 disebutkan bahwa. Pendidikan nasional berfungsi mengembangkan kemampuan dan membentuk watak serta peradapan bangsa yang bermartabat dalam rangka mencerdaskan kehidupan bangsa, bertujuan untuk berkembangnya potensi peserta didik agar menjadi manusia yang beriman dan bertakwa kepada Tuhan yang Maha Esa, berakal mulia, sehat berilmu, cakap, kreaktif, mandiri, dan menjadi warga negara yang demokratis serta bertanggun jawab.
Pemerintah berupayah untuk meningkatkan mutu pendidikan dengan berbagai hal, yang salah satunya adalah dengan mengadakan ujian nasional. Ujian Nasional merupakan sebuah penentu keberhasilan bagi seseorang peserta didik dalam belajar disuatu sekolah.

Hayati (2011) menjelaskan bahwa Ujian Nasional (UN) adalah salah satu implementasi pelaksanaan penilaian oleh pemerintah dengan tujuan untuk menilai pencapaian kompetensi lulusan secara nasional pada mata pelajaran Bahasa Indonesia, Matematikan, dan Ilmu Pengetahuan Alam (IPA) dan mendorong tercapainya target wajib belajar pendidikan dasar yang bermutu. sedangkan hasil UN digunakan sebagai salah satu pertimbangan untuk pemetaan mutu satuan pendidikan, dasar seleksi masuk jenjang periode penendidikan berikutnya, penentuan kelulusan peserta didik dari satuan pendidikan, dan dasar pembinaan dan pemberian bantuan kepada satuan pendidikan dalam upaya meningkatkan mutu pendidikan. 
Permasalahan yang digunakan saat ini adalah bagai mana agar peserta didik dapat lulus dengan nilai yang baik, karena selain lulus sebagai target utama peserta didik, mereka juga harus sukses dalam seleksi penerimaan siswa baru di SMA. Mereka harus belajar lebih giat lagi, serta mengubah pola belajar yang tadinya masih kurang maksimal menjadi lebih maksimal mungkin agar dapat masuk ke sekolah lebih tinggi yang diinginkan.

Berbagai usaha dilakukan untuk dapat mencapai nilai yang maksimal dalam ujian nasional. Usaha tersesebut dilakukan oleh pihak pemerintah, sekolah, peserta didik dan orang tua dari peserta didik itu sendiri, misalnya pihak pemerintah melalui dinas pendidikan menyelenggarakan latihan-latihan ujian, pihak sekolah dengan menambahkan jam mengajar (les), pihak orang tua dengan mengikut sertakan peserta didik melalui bimbingan-bimbingan belajar diluar sekolah dan dari pihak peserta didik sendiri dengan meningkatkan volume serta pola belajarnya.

Namun demikian, walaupun berbagai upaya sudah dilakukan oleh berbagai pihak untuk mendapatkan hasil yang maksimal dari ujian nasional, tetapi masih saja ada kendala-kendala yang di hadapi, baik oleh peserta didik, orang tua, sekolah, dan oleh pemerintah.

Berdasarkan uraian tersebut peneliti terdorong untuk mengadakan penelitian tentang bagaimana pola belajar siswa kelas VIII SMP dalam menghadapi ujian nasiona. Oleh karena itu peneliti menetapkan judul "Hubungan Antara Pola Belajar Siswa Kelas VIIIA SMP untuk persiapan kelas IX dalam menghadapi Ujian Nasional Sekolah Tingkat satuan (SMP) YPK Bethel Aimas tahun ajaran 2016/2017'. Untuk Mengetahui Hubungan Antara Pola Belajar Dengan Prestasi Belajar IPA Pada Siswa SMP YPK Bethel Aimas.

\section{METODE PENELITIAN}

Penelitian ini merupakan jenis penelitian Kuantitatif. penelitian ini merupakan pengamatan atau penyelidikan yang kritis untuk mendapatkan keterangan yang baik terhadap suatu pola belajar tertentu di dalam lokasi SMP YPK Bethel Aimas tertentu atau suatu studi ekstensif yang dipolakan untuk memperoleh informasi-informasi yang dibutuhkan (Daniel, 2001).: (1) mendeskripsikan keadaan alami yang hidup saat itu, (2) mengidentifikasi secara terukur keadaan sekarang untuk dibandingkan dan (3) menentukan hubungan sesuatu yang hidup di antara kejadian spesifik (Sukardi, 2003). Data ini dikaji dengan metode penelitian kuantitatif dan data kualitatif

Data kuantitatif adalah data yang berbentuk angka atau data kualitatif yang diangkakan. Data kualitatif yang diangkakan misalnya terdapat dalam skala pengukuran. Suatu pernyataan atau pertanyaan yang memerlukan alternatif jawaban, dimana masing- masing Baik diberi angka 3, Cukup 2, kurang 1, dan tidak (Sugiyono, 2002). Penelitian kuantitatif mengambil jarak antara peneliti dengan objek yang diteliti.

Penelitian ini dilaksanakan di sekolah SMP YPK Bethel Aimas pada tahun ajaran 2015/2016. Aktivitas penelitian ini secara secara kusu kelas VIIIA SMP YPK Bethel Aimas dilaksanakan selama dua bulan, sejak bulan Juli sampai dengan bulan Agustus 2016.

Sampel adalah sebagian atau wakil populasi yang diteliti (Arikunto, 2002; Furchan, 2004). Sampel adalah sebagian dari jumlah dan karakteristik yang dimiliki oleh populasi (Sugiyono, 2001). Sampel dalam penelitian ini adalah 22 Siswa Kelas VIII A SMP YPK Bethel Aimas tahun ajaran 2016/2017. Alat atau Instrumen Pengambilan Data yang dipakai adalah Wawancara, Angket Siswa dan Dokumentasi.

Dalam penelitian Kuantitatif, prosedur pengumpulan data penelitian adalah sebagai berikut: Mendata sekolah tempat penelitian. Mengurus surat ijin penelitian kepada kepala sekolah SMP YPK Bethel Aimas. Melakukan pengolahan data hasil penelitian.

Wawancara dilakukan untuk menghasilkan informasi dari siswa tentang kemampuan pola belajar dalam melakukan proses belajar mengajar yang menggunakan pola belajar IPA di sekolah. Wawancara juga dilakukan terhadap kepala sekolah selaku pimpinan dalam sekolah tersebut untuk memeperoleh data kualitatif. Wawancara dilakukan pada saat penelitian.

Angket siswa untuk menghasilkan informasi siswa tentang keadaan siswa di sekolah tersebut. Dan membicarakan tentang Pola belajar dengan prestasi belajar. Siswa yang di maksud dalam penelitian ini adalah semua siswa kelas VIII A di sekolah SMP YPK Bethel Aimas. Angket diberikan pada saat penelitian dan hasil angket diserahkan dalam waktu satu hari.

- Dokumentasi dilakukan untuk penunjang pada saat melakukan penelitian sebagai penunjang bukti fisik penelitian.

Item tes tertulis berdasarkan kerangka isi sebagai pedoman dalam setiap kategori, kisi-kisi itu dapat ditarik secara beruntun, item-item tes dan jumlah yang sesuai dengan bobot kategori tersebut secara keseluruhan. Pemakaian tes harus mempertimbangkan apakah isi dan tujuan yang terdapat dalam wilayah isi sudah terpenuhi atau belum. Jika hal tersebut berarti item tes telah memiliki validitas isi dalam kategori tersebut. Validitas tes yang baru tersebut dapat dicari dengan rumus di bawah ini:

Reliabilitas menurut Arikunto (2006:178) mengandung pengertian bahwa "Suatu instrumen cukup dapat dipercaya untuk digunakan sebagai alat pengumpul data karena instrumen itu sudah baik". Dalam reliabilitas digunakan untuk mencari keajegan 
dari instrumen yang akan digunakan dalam tes. Sebelum tes essai diberikan kepada sampel terlebih dahulu tes diujicobakan kepada populasi di luar sampel, kemudian dihitung reliabilitas tes untuk mengetahui tingkat keajegan tes tersebut.

Setelah diketahui reliabilitas tes baru disebarkan besarnya koefisien korelasi. Arikunto (2006:59) menyatakan sebagai berikut :

Tingkat kevalid dan tes yang diharapkan adalah yang memenuhi kriteria baik, cukup, sampai kurang, sesuai dengan interpretasi waliditas di atas. Jika tes angket memenuhi kriteria yang diharapkan, maka tes tersebut diberikan kepada sampel.

Teknik Analisis data adalah analisis kuantatif Data yang di ambil dari pengamatan pada siswa kelas VIIIA SMP YPK Bethel Aimas. Teknik Analisis data awal digunakan untuk mengetahui apakah pola belajara dan prestasi belajar meningkat atau tidak secara signifikan. Dalam pengelolahan dan penganalisisan data tersebut digunakan spss.

Langkah-langkah yang ditempuh dalam penggunaan SPSS untuk pengelolahan analisis data kuantitatif tersebut rumus teknik analisis data yaitu uji hipotesis. Uji hipotesis yang digunakan adalah validitas dan reabilitas. Validitas adalah suatu ukuran yang menunjukan tingkat-tingkat kevalidan atau kealihan sesuatu instrumen.

Reabilitas yaitu mengandung pengertian bahwa "Suatu instrumen cukup dapat dipercaya untuk digunakan sebagai alat pengumpul data karena instrumen itu sudah baik". Dalam reliabilitas digunakan untuk mencari keajegan dari instrumen yang akan digunakan dalam tes.

Dalam Intrumen hal ini, peneliti menggunakan validitas isi (content, validity) yaitu validitas yang didasarkan butir-butir item tes,Angket yang sesuai dengan kurikulum dan dikonsultasikan dengan pembimbing. Validitas isi berguna untuk menunjukkan sejauh mana instrumen tersebut mencerminkan isi yang dikehendaki. Menurut Arikunto (2006:168) "Instrumen dikatakan valid apabila mampu mengukur apa yang diinginkan. Sebuah instrumen dikatakan valid apabila dapat mengungkap data dari variabel yang diteliti secara tepat".

\section{PEMBAHASAN}

Berdasarkan hasil perhitungan data intrumen adalah Baik, Cukup, Kurang, maka hasil skor distribusi frekuensi siswa SMP YPK Bethel Aimas pada kelas VIII A dengan jumlah 22 siswa dapat dilihat dalam tabel 4.1 berikut ini

Tabel 4.1. Hasil Data Angket Siswa

\begin{tabular}{|l|c|c|c|c|}
\hline \multicolumn{1}{|c|}{ Nama } & Baik & Cukup & Kurang & Skor \\
\hline Apner & 5 & 10 & 5 & 22 \\
\hline Brian & 14 & 6 & - & 20 \\
\hline Dorci & 5 & 7 & 8 & 20 \\
\hline Erek & 11 & 7 & 2 & 20 \\
\hline Friska & 5 & 8 & 7 & 20 \\
\hline
\end{tabular}

\begin{tabular}{|l|c|c|c|c|}
\hline Frans & 6 & 6 & 8 & 20 \\
\hline Meilana & 13 & 7 & - & 20 \\
\hline Melvin & 13 & 5 & 2 & 20 \\
\hline Marselina & 11 & 8 & 1 & 20 \\
\hline Margareta & 4 & 9 & 7 & 20 \\
\hline Meilisa & 9 & 8 & 3 & 20 \\
\hline Onesimus & 8 & 9 & 3 & 20 \\
\hline Primus & 8 & 7 & 4 & 20 \\
\hline Stevani & 8 & 9 & 3 & 20 \\
\hline Syeni & 3 & 13 & 4 & 20 \\
\hline Selvitas & 19 & 1 & - & 20 \\
\hline Yosafat & 11 & 6 & 3 & 20 \\
\hline Yohanis & 11 & 7 & 2 & 20 \\
\hline Domansal & 6 & 8 & 6 & 20 \\
\hline Viky & 8 & 11 & 1 & 20 \\
\hline Brigita & 18 & 2 & - & 20 \\
\hline Novi & 7 & 9 & 4 & 20 \\
\hline Jumlah & 204 & 165 & 64 & 440 \\
\hline
\end{tabular}

Tabel Data instrumen yang diambil dari siswa-siswi diatas ini dengan memberikan Angket kepada siswa-siswi tentang pola-pola belajar IPA di rumah maupun di sekolah.

Tabel 4.2. Kategori Pola Belajar Siswa

\begin{tabular}{|l|l|c|}
\hline Kategori & $:$ & Persentsi \\
\hline Baik & $:$ & $3=\geq 2$ \\
\hline Cukup & $:$ & $2=1-2$ \\
\hline Kurang & $:$ & $1=1-2 \leq$ \\
\hline
\end{tabular}

Data-data ini peneliti menguji Statistik dapat di lihat data hasil pada tabel di bawah ini. Sehingga ada siswa yang memilih skor maksimal.

Tabel 4.3. Hasil Pola Belajar Siswa

\begin{tabular}{|c|l|c|}
\hline No & Kategori & Persentasi \\
\hline 1 & Baik & $22 \%$ \\
\hline 2 & Cukup & $22 \%$ \\
\hline 3 & Kurang & $18 \%$ \\
\hline
\end{tabular}

Berdasarkan tabel 4.1. di atas di peroleh data nilai dari pola belajar dengan prestasi belajar yang diambil dari angket dan observasi pada siswa kelas VIIIA secara keseluruhan di kelas VIII A yaitu nilai kurang sebesar $=18 \%$ nilai cukup $=22 \%$ dan nilai tertinggi baik sebesar $=22 \%$. Setelah diberikan pembelajaran materi sistem pernafasan pada manusia melalui metode ceramahtanyajawab dengan menggunakan media kapasitas vital paru-paru pada manusia diberikan tes polabelajarkelompok prestasi belajar, diperoleh data siswa yang diberi pembelajaran dengan media kapasitas vital paruparu pada manusia sehingga memperoleh nilai 
baik $=22 \%$ dengan nilai cukup $=22 \%$ nilai kurang $=18 \%$

Berikut ini disajikan data dari satu kelas subjek penelitian yaitu; kelas VIII A SMP YKK Bethel Aimas. yang terdiri dari jumlah siswa 22 yang diambil dari Variabel baik, cukup, kurang. Variabel dalam penelitian ini terdiri atas dua variabel bebas dan satu variabel terikat. Variabel bebas pertama terdiri atas pola belajar, dan media kapasitas vital paru-paru pada manusia, variabel bebas kedua terdiri atas waktu belajar dan sering belajar siswa dan pola belajar siswa. Sedangkan variabel terikat yang dipilih adalah prestasi belajar IPA siswa, khususnya kompetensi dasar sistem pernapasan pada manusia untuk hubungannya dengan bernafas, kehidupan, dan kesehatan.

Wawancara dilakukan kepada guru kelas VIIIA untuk mengetahui faktor-faktor yang mempengaruhi Pola belajar dengan Prestasi belajar siswa kelas VIIIA dalam pembelajaran kurikulum KTSP yang dilengkapi dengan dukumentasi dan catatan lapangan. Data-data yang diperoleh kemudian dianalisa untuk menunjukkan kemungkinan adanya peningkatan belajar IPA yang dialami siswa dalam pembelajaran kurikulum KTSP dilihat dari perolehan hasil angket.

Prestasi belajar IPA pada siswa kelas VIIIA dalam konsep sistem pernapasan dapat dilihat dari hasil ankget kepada siswa-siswi. Diperoleh hasil "Baik" $=22 \%$ nilai pada siswa kelas VIIIA di dalam aspek "Cukup" dalam belajar IPA pada konsep Sistem Pernafasan pada manusia siswa mampu dengan persentase sebesar 22\%, pemahaman siswa kelas VIIIA dalam aspek "Kurang" dalam belajar IPA pada konsep Sistem pernafasan manusia mendekati mampu, dengan persentase sebesar $18 \%$ dan pemahaman siswa kelas VIIIA dalam aspek media belajar IPA pada konsep Sistem pernafasan pada manusia mendekati mampu, dengan persentase baik sebesar $4.54 \%$.

Wawancara yang dilakukan kepada guru kelas VIIIA dikelas. kurikulum KTSP mengenai peningkatan atau prestasi belajar IPA dan faktorfaktor yang mempengaruhi peningkatan atau prestasi belajar IPA siswa adalah motivasi siswa yang sangat tinggi, sarana belajar yang sederhana dan pemahaman guru yang sangat mantap untuk melaksanakan proses pembelajaran yang maksimal menyesuaikan dengan penerapan kurikulum KTSP. Guru sudah memaksimalkan penggunaan buku guru dan buku siswa dalam pelaksanaan proses pembelajaran dan memberikan motivasi yang diharapkan dapat mendorong kemauan siswa dalam belajar IPA.

Hasil belajar siswa merupakan hasil dari penilaian kemampuan kognitif siswa yang diperoleh setelah mengerjakan soal tes angket dan observasi. Nilai evaluasi tersebut diperoleh dari peningkatan nilai IPA satu kelas untuk mengetahui tingkat keefektifan metode pembelajaran Langsun. Penelitian ini dilakukan pada satu kelompok yaitu kelas VIII A.

Berdasarkan hasil analisis peningkatan nilai IPA, peningkatan nilai kelas VIII A lebih tinggi. Hal ini dapat dilihat dari hasil angket dan observasi data peningkatan nilai antara siswa masing- masing diperoleh (80\%), karena Rata- rata peningkatan nilai hasil belajar kelas (VIII A) dengan penerapan model Pembelajaran langsun dan kooperatif lebih baik dari pada kelas kontrol Hal ini dikarenakan pembelajaran dengan model langsun/kooperatif dapat memotivasi belajar siswa sehingga siswa tertarik dalam mengikuti proses pembelajaran. Hasil belajar siswa sangat dipengaruhi oleh aktivitas dan juga motivasi siswa dalam proses pembelajaran.

Motivasi dalam belajar, keaktifan dan keterlibatan siswa dalam proses pembelajaran merupakan beberapa faktor pendukung keefektifan belajar. Adanya motivasi dalam belajar maka akan menjadikan siswa yang pasif menjadi aktif, dan dengan keaktifan siswa yang tinggi maka akan membangkitkan rasa ingin tahu siswa dalam belajar dan secara otomatis akan meningkatkan hasil belajar siswa.

Motivasi siswa dapat timbul karena ketertarikan pada model pembelajaran yang menarik. Hasil tanggapan siswa terhadap model pembelajaran (Langsu) diperoleh data sebanyak $4.54 \%$ siswa menyatakan tertarik dengan diterapkannya model Pembelajaran lansun dan koperatif karena pembelajaran dengan model ini dapat membuat siswa lebih paham, lebih aktif, dan membuat siswa berfikir kritis.

Aktivitas belajar siswa memiliki pengaruh terhadap hasil belajar siswa. Hal ini sesuai dengan pendapat Dalyono (2005), bahwa belajar adalah proses yang aktif sehingga apabila siswa tidak terlibat dalam berbagai aktivitas belajar sebagai respon siswa terhadap stimulus guru, tidak mungkin siswa dapat mencapai hasil belajar yang dikehendaki. Keaktifan siswa dalam proses pembelajaran akan menumbuhkan motivasi belajar dan pada akhirnya akan berpengaruh terhadap peningkatan hasil belajar. Hal ini sesuai dengan pendapat Suparno (1997) dan didukung oleh pendapat Nasution (2000) yang mengemukakan bahwa keaktifan dan keterlibatan siswa dalam proses belajar mengajar merupakan salah satu faktor pendukung keberhasilan belajar siswa.

Hasil penelitian Susilowati (2005) juga menyatakan bahwa penerapan model pembelajaran langundan kooperatif dapat meningkatkan peran aktif siswa pada konsep sistem eksresi. Hal serupa juga diperoleh dalam penelitian Trisnawati (2005) yang menyatakan bahwa pembelajaran konsep pratek kapasitas vital paru-paru pada manusia dengan menggunakan model pembelajaran Langsu 
dankooperatif dapat meningkatkan aktivita belajar siswa.

Hal ini dapat dilihat bahwa aktivitas siswa selama proses pembelajaran dengan menggunakan model pembelajaran demontrasi meningkat ditiap pertemuan (tabel 4.1.) Pada pertemuan di kelas (VIII A), siswa masih belum terbiasa dengan menggunakan pembelajaran langsun. Hal ini terlihat pada saat presentasi mereka masih malu atau tidak berani untuk mengemukakan pendapat mereka, tetapi pada presentasi yang berikutnya siswa tampak sudah terbiasa dengan suasana belajar dengan demontrasi sehingga suasana kelas menjadi lebih hidup.

Metode ceramah memang lebih mudah dilaksanakan dan tidak membutuhkan alat bantu khusus, serta dapat membuat pembelajaran menjadi lebih jelas dan lebih kongkrit, akan tetapi dalam penerapan metode ini memerlukan keterampilan guru secara khusus. Selain itu, metode ini juga memerlukan kesiapan dan perencanaan yang matang serta memerlukan waktu yang lama. Kelemahan metode ceramah adalah siswa kurang dirangsang untuk aktif dan metode ini hanya menempatkan siswa sebagai pendengar dan pencatat (Rustaman 2003). Pada pertemuan kedua kelas VIIIA, masing-masing siswa membandingkan data hasil praktikum di depan kelas, kemudian masing-masing siswa mencoba mengemukakan pendapatnya sehingga suasana pembelajaran menjadi lebih hidup.

Hal ini berbeda dengan kondisi siswa di kelas pembanding yang cenderung diam, dan masih malu atau tidak berani untuk mengemukakan pendapat, jalannya diskusi masih didominasi oleh beberapa siswa. Dalam kegiatan diskusi kelompok mereka juga sudah tidak malu-malu lagi dalam bertanya, mengemukakan pendapat kepada anggota lain.

Dalam kegiatan presentasi, sudah tampak keantusiasan dari masing-masing siswa untuk menyampaikan hasil diskusi kelompoknya. Siswa sudah tidak malu-malu lagi dalam bertanya, menjawab pertanyaan dan mengemukakan pendapatnya. Aktivitas siswa kelas VIII A lebih baik. Hal ini terjadi karena pembelajaran lebih memberikan kesempatan kepada siswa 22 untuk beraktivitas sehingga belajar lebih menyenangkan. Belajar dengan suasana menyenangkan menyebabkan otak mudah menerima materi dan dapat terekam lama dalam ingatannya.

Pembelajaran yang dikaitkan dengan lingkungan, siswa akan memperoleh pengalaman dan pengetahuan baru yang tidak didapatkan di sekolah, sehingga dengan pengalaman baru itu diharapkan lebih bertahan lama dalam ingatannya. Dengan melakukan kegiatan yang dilakukan sendiri siswa mengetahui tidak hanya secara teoritis tetapi juga secara praktis (Darsono dkk 2000).

Pembelajaran yang efektif adalah pembelajaran yang berpusat pada siswa. Hal ini sesuai pendapat Ridlo (2005) bahwa melakukan kegiatan yang dilakukan sendiri akan mempermudah siswa mempelajari suatu materi pelajaran dan untuk mengingatnya kembali. Dengan demikian, hasil belajar siswapun akan menjadi lebih optimal.

Peningkatan aktivitas dan hasil belajar siswa tidak lepas dari peran guru, baik sebagai fasilitator maupun motivator dalam proses pembelajaran. Kinerja guru yang baik dapat berpengaruh pada meningkatnya aktivitas siswa sehingga berpengaruh terhadap peningkatan hasil belajar siswa.

Dalam pelaksanaan pembelajaran guru berusaha mempertahankan perhatian siswa untuk terus tertuju pada proses pembelajaran. Guru mengorganisasikan siswa dalam kelompok, mengkondisikan kelas dan berinteraksi dengan siswa serta berupaya agar suasana kelas lebih menyenangkan. Secara garis besar guru sudah mampu mengelola kelas dengan baik, tetapi masih perlu ditingkatkan sehingga kinerja guru lebih optimal.

Untuk menunjang hal ini Sardiman (2005), mengemukakan bahwa kreativitas guru juga mutlak diperlukan agar dapat merencanakan kegiatan siswa yang sangat bervariasi. Pelaksanaan proses model pembelajaran lansung yang dilakukan di SMP YPK Bethel Aimas masih terdapat beberapa aspek yang pelaksanaanya belum sempurna yaitu dalam pengorganisasian siswa pada pertemuan pertama, hal ini dikarenakan pada pertemuan pertama siswa belum terbiasa dengan model pembelajaran pembelajaran lansung. Akan tetapi pada pertemuan selanjutnya siswa lebih mudah diatur dalam kegiatan pembelajaran.

Hal yang menjadi kendala dalam pelaksanaan pembelajaran pembelajaran lansung adalah guru aktif dalam mengelola waktu. Hal ini kemungkinan dikarenakan guru belum terbiasa dengan model pembelajaran yang diterapkan. Alternatif penyelesaian yang bisa dilakukan yaitu yang pertama guru hendaknya lebih tegas dalam pengaturan waktu, guru hendaknya mengingatkan siswa bila siswa mulai keluar dari tugas yang semestinya.

Guru hendaknya bertindak sebagai fasilitator yang memberikan kemudahan bagi siswa sehingga mampu mendorong siswa untuk belajar seoptimal mungkin sesuai dengan kemampuan siswa. Ketiga, guru hendaknya selalu memotivasi siswa untuk senantiasa belajar.

Dari hasil analisis tanggapan siswa terhadap pelaksanaan pembelajaran materi Sistem pernafasan pada manusia dengan menerapkan model pembelajaran lansung memberikan respon yang positif. Tanggapan siswa selama proses pembelajaran IPA untuk kelas VIII A adalah sebanyak $22 \%$ siswa merasa tertarik terhadap pembelajaran yang telah diberikan. Diterapkannya pembelajaran langsung mampu menciptakan suasana kelas yang menyenangkan, hal ini bisa dilihat dari respon siswa sebanyak $100 \%$ yang menyatakan bahwa siswa meyukai suasana kelas pada saat 
pembelajaran IPA berlangsung. Sebanyak 18\% siswa menyatakan tidak menyukai kegiatan praktikum.

Hasil pengamatan dalam proses pembelajaran menunjukan bahwa beberapa siswa kesulitan untuk membedakan jenis cara bernafas yang terkandung dalam kapasitas vital paru-pari karena salah bernafas. Alternatif bernafas yang dapat dilakukan guru siswa hendaknya memberikan bimbingan dan pelatihan yang lebih banyak agar siswa menjadi lebih terampil untuk melakukan uji coba pernafasan baik Sebanyak 90\% siswa menyatakan lebih mudah dalam memahami materi dengan diterapkannya model pembelajaran langsun.

Secara umum pembelajaran dengan penerapan model Pembelajaran demontrasi dapat meningkatkan hasil belajar siswa pada materi sistem pernafasan pada manusia Hasil pembahasan SPSS untuk menguju apakah ada hubungan antara pola belajar dengan prestasi belajar IPA biologi dengan media kapasitas vital paru-paru terhadap pola belajar dengan prestasi belajar siswa maka nilai baik $>=$ $22 \%$. dengan nilai cukup $>=22 \%$. Dan nilai kurang $>=4.54 \%$. dan kurang sekali $>=18 \%$ maka nilai rata-rata pola belajar dan prestasi belajar IPA $=90 \%$ sehingga media pembelajaran melalui media kapasitas vital paru-paru memberikan pengaruh pada signifikan terhadap pola belajar dan prestasi belajar Media pembelajaran IPA biologi kompetensi dasar sistem pernafasan pada manusia untuk selama ini yang banyak digunakan adalah metode Ceramah Tanya jawab.

Metode ini sangat menarik dan siswa sangat aktif dalam mengikuti proses pembelajaran. Agar proses pembelajaran menjadi menarik maka guru berusaha untuk mencari media pembelajaran yang membuat siswa menjadi antusiasi yang pada akhirnya akan berdampak positif dengan hasil pembelajaran kognitifnya. Hasil dilihat dari rata-rata prestasi siswa, yang diberi pembelajaran dengan media kapasitas vital paru-paru mendapatkan

Konsekuensinya perubahan sikap ilmiah siswa telah terpenuhi, dan berdasarkan penelitian sebelumnya bahwa kegiatan tersebut telah memberikan dampak positif pada pola dengan prestasi belajar IPA siswa. Hasil penelitian tersebut menunjukkan bahwa hasil evaluasi dari masingmasing nilai menunjukkan adanya peningkatan positif sikap ilmiah siswa diketahui yang berubah secara signifikan. Penelitian tersebut difokuskan pada materi IPA biologi yang memang lebih banyak materi yang bersifat hafalan.

Metode ceramha Tanya jawab dalam penelitian tersebut berperan sebagai alat bantu dalam proses visualisasi. Hal lain yang mendukung keberhasilan media kapasitas vital paru-paru dalam memberikan efek pola dengan prestasi belajar yang lebih baik adalah siswa dapat melihat aliran sistem pernafasan pada manusia dengan mengamati secara langsung sehingga lebih memberikan kesan mendalam terhadap pemahaman informasi yang baik, hanya dengan metode tertentu saja.

\section{KESIMPULAN}

Berdasarkan analisis data dan pengujian hipotesis dapat disimpulkan bahwa terdapat Hubungan antara pola belajar siswa dengan hasil belajar siswa . Hasil belajar IPA biologi siswa pada konsep sistem pernafasan pada manusia hal ini terlihat pada perhitungan SPSS diperoleh nilai baik sebesar $\geq 22 \%$ cukup sebesar $22 \%$ dan kurang sebesar $18 \%$ maka ada hubungan antara pola belajar dengan prestasi belajar IPA pada siswa kelas VIII A SMP YPK Bethel Aimas. Hasil derajat kebebasan = $90 \%$ dengan taraf signifikasi $5 \%$.

\section{DAFTAR PUSTAKA}

A.M Sardiman. (2009). Interaksi dan Motivasi Belajar Mengajar. Jakarta. PT Rajawali Pers.

Ahmad, Mudzakir. (1997). Psikologi Pendidikan. Bandung : Pustaka Setia.

Alwi, Hasan. 2005. Kamus Besar Bahasa Indonesia pola Edisi Ketiga. Jakarta: Balai Pustaka

Anonymous, 2009, Undang-Undang No 20 RI. tahun 2013 pasal 3 Nasional, Departemen Pendidikan Nasional Republik Indonesia

Martinis Yamin. 2007 Profesionalisasi Guru dan Implementasi KTSP. Jakarta : Gaung Persada.

Mila Ratnawati. (1996). Hubungan antara Persepsi Anak terhadap Suasana Keluarga, Citra Diri, dan Motif Berprestasi dengan Prestasi Belajar pada Siswa Kelas V SD Ta'Miriyah Surabaya. Jurnal Anima Vol XI No. 42.

Nana, Sudjana. (2001). Penilaian Hasil Proses Belajar Mengajar. Cetakan ketujuh. Bandung : PT Remaja Rosdakarya.

Ratna Wilis, D. (1996). Teori-Teori Belajar. Jakarta : Penerbit Erlannga.

Sia, Tjundjing. (2001). Hubungan Antara IQ, EQ, dan QA dengan Prestasi Studi Pada Siswa SMU. Jurnal Anima Vol.17 no.1

Saifuddin, Azwar. (1997). Reliabilitas dan Validitas. Yogyakarta : Pustaka Balajar Offset.

Sheizan. 2007 (6 Desember). Pengertian Biologi Forum SMPN 2 Bandung. Tersedia di : http://smpn2bdg.gettalk.net/t12-pengertianbiologi [1 Agustus 2012]

Sukardi. 2003. Metodologi Penelitian Kependidikan.Jakarta. Bumi Aksara.

Sugiyono. 2009. Metode Penelitian Kuantitatif dan Kualitatif. CV.Alfabeta: Bandung.

Saifuddin Azwar. (1998). Tes Prestasi Fungsi dan Pengembangan Pengukutan Prestasi balajar. Yogyakarta : Pustaka Pelajar Offset.

Sutrisno Hadi. (2000). Statistik 2. Yogyakarta : Andi Offset.

Syaiful Bakrie D. (1994). Prestasi belajar dan kompetensi guru. Surabaya : Usaha Nasional. 
Winkel, W.S. (1996). Psikologi Pengajaran. Jakarta: Grasindo.

Fairuz El Said. 2012. Pendidikan- Konsep SCL (Student Centered Learning) Diakses tanggal 20 Maret 2012 (http:// fairuzelsaid. wordpress. com/ 2010/08/28/pendidikan-konsep-scl-studentcenterd-learning)

Erman \& Edi Mintarto. 2001. Memacu Kemampuan Berpikir Formal Siswa Melalui Pembelajaran IPA Sejak Dini. FIK Unesa, 4, 90-93 